\title{
Mangrove macroalgae as biomonitors of heavy metal contamination in a tropical estuary, Malaysia
}

\begin{abstract}
Until recently, there have been only few published reports concerning the use of mangrove macroalgae as biomonitors to assess the estuarine metal contamination. Therefore, the present study was an effort to investigate the biomonitoring of metal contamination using mangrove macroalgae in the tropical Miri estuary of Sarawak, Malaysia. The metal concentrations $(\mathrm{Cu}$, $\mathrm{Fe}, \mathrm{Mn}$, and $\mathrm{Zn}$ ) were determined in the surface sediments, estuarine water, and six dominant macroalgae species that epiphytically grow on mangrove pneumatophores. The results showed that the scheme of metal occurrences in estuarine surface water and sediments was Fe $>\mathrm{Mn}>\mathrm{Zn}>\mathrm{Cu}$ and $\mathrm{Fe}>\mathrm{Zn}>\mathrm{Mn}>\mathrm{Cu}$, respectively. Among the studied metals in algal tissues, irrespective of macroalgal species, the concentration of $\mathrm{Fe}$ was found to be the highest. Significant positive correlations were found between $\mathrm{Cu}$ and $\mathrm{Zn}$ in all macroalgal species (except Caloglossa ogasawaraensis and Dictyota sp.), indicating the common origin of those elements. Concentrations of each of the studied metal in algal tissues varied among macroalgal species, probably because of the differences of structure, age, and growth of thallus among macroalgal species. To our knowledge, this is the first comprehensive report describing the biomonitoring of metal contamination using macroalgae from Malaysian mangrove systems.
\end{abstract}

Keyword: Mangrove macroalgae; Bioconcentration factor; Bioaccumulator; Phytoremediation; Heavy metal 